Proc. Estonian Acad. Sci. Biol. Ecol., 2004, 53, 4, 236-250

\title{
Historical review of the literature on phytobenthic investigations in the Gulf of Riga
}

\author{
Georg Martin $^{\mathrm{a} *}$, Erich Kukk ${ }^{\mathrm{b}}$, Henn Kukk $^{\mathrm{a}}$, and Jonne Kotta ${ }^{\mathrm{a}}$ \\ ${ }^{\text {a }}$ Estonian Marine Institute, University of Tartu, Mäealuse 10a, 12618 Tallinn, Estonia \\ b Institute of Ecology and Botany, University of Tartu, Lai 40, 51005 Tartu, Estonia
}

Received 28 March 2001, in revised form 22 March 2004

\begin{abstract}
Phytobenthic investigations in the area of the Gulf of Riga date back as far as the end of the 18th century. Since then a large number of investigations have been carried out in the area resulting in numerous publications in various local and wide-spread European languages. The aim of the present paper is to give a detailed review of the knowledge concerning the species composition and quantitative distribution of phytobenthos in the area. For historical reasons, a great part of the scientific literature from the area is in the Russian, Estonian, or Latvian language. These works contain valuable information useful now that investigations have become truly international and large-scale around the Baltic Sea. The present paper gives a review of 85 papers or other published materials and presents the most important conclusions and facts. A comparative list of species of macroalgae and phanerogams ever identified from the area is given with references to the authors.
\end{abstract}

Key words: macrophytobenthos, Gulf of Riga.

\section{INTRODUCTION}

The Gulf of Riga is considered to be one of the most eutrophied basins in the Baltic Sea. Therefore it was recently placed under close investigation in terms of description and modelling of biogeochemical processes and biodiversity. As $20 \%$ of the total area of the Gulf is shallower than $10 \mathrm{~m}$ the role of benthic littoral communities in this ecosystem should be of great importance and possible largescale and long-term developments in the functioning of the Gulf of Riga ecosystem are expected to have a strong effect on the littoral biota.

The aim of the present paper is to give a detailed review of the knowledge concerning the species composition and quantitative distribution of phytobenthos in the area. Due to the history of the area a large part of the scientific literature concerning it is written in Russian, Estonian, or Latvian, and is so not available

* Corresponding author, georg.martin@ut.ee 
for direct reading to a great majority of scientific public around the Baltic Sea. However, these works contain valuable scientific information useful at the present time when scientific investigations have become truly international and large-scale around the Baltic Sea.

The publications dealing with the algae of the Baltic Sea, including the Gulf of Riga, may be conventionally divided into two groups covering also two different periods. The first will cover the floristic lists and taxonomic studies mainly until World War II, and the second the research done since the end of the 1950s in the field of bioproduction and algal communities. The location of the study area is shown in Fig. 1.

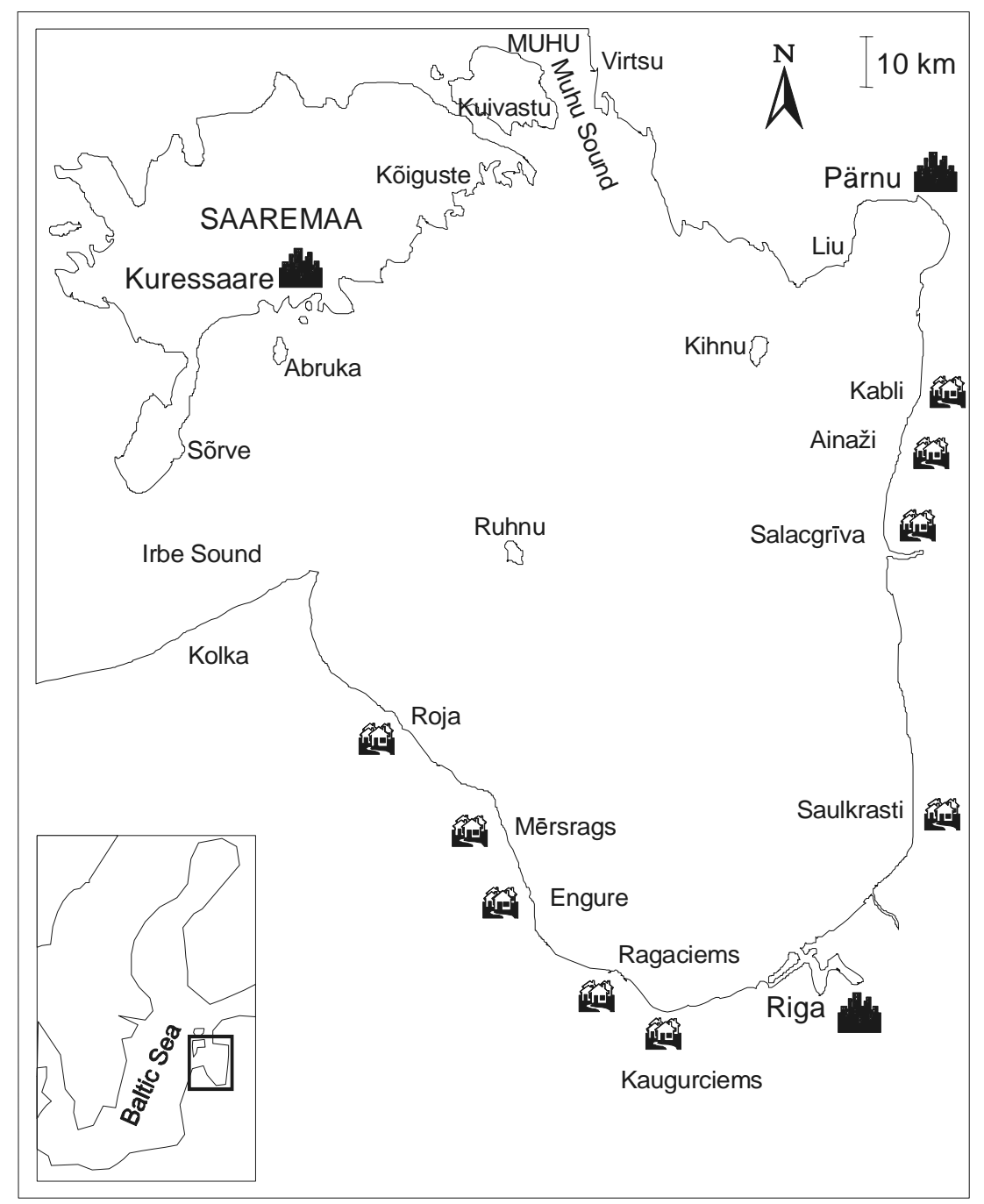

Fig. 1. Location of the study area. 


\section{HISTORICAL STUDIES WITH FLORISTIC ORIENTATION}

The first written record about the macroalgae of the Eastern Baltic, including evidently also the Gulf of Riga, can be found in Versuch einer Naturgeschichte von Livland (1778) by Jacob Benjamin Fischer, a pupil of C. Linné. The initials of the author on the title page of the first edition are J. L., but in the second edition (1791) these are already J. B., although both works have been written by one and the same researcher. In both works the bladder wrack (Fucus vesiculosus) is mentioned without any concrete data on the finds; in the second work also the species Furcellaria lumbricalis (= Fucus lumbricalis) and Enteromorpha (=Ulva) intestinalis are named. Between these two monographs the author published (1784) Zusätze zu seinem Versuch einer Naturgeschichte von Livland, in which he named Ulva intestinalis and three species of Conferva. In Grindel's Botanisches Taschenbuch für Liv-, Kur- und Ehstlands (1803) again the bladder wrack and agar-agar, two species of Enteromorpha (=Ulva), and some species of Chara are mentioned; unfortunately, without showing where exactly the last were found. In 1805 Oeconomisch-technische Flora für Liv-, Ehst- und Kurlands by Friebe was published, where the bladder wrack is again mentioned. Von Luce (1823) in his Topographische Nachrichten von der Insel Oesel in mediczinischer und ökonomischer Hinsicht describes accumulations of bladder wrack (Fucus vesiculosus) cast ashore, which coast dwellers used as a fertilizer. He also mentions the coastal water species Chara hispida.

The above-mentioned publications are followed by Eichwald's (1847, 1849, 1852) three works entitled "Erster..., Zweiter..., Dritten Nachtrag zum Infusiorenkunde Russlands", respectively. These works deal mainly with planktonic microorganisms. However, in the third work Eichwald mentions also the occurrence of Chara in the vicinity of bathing places at Kuressaare. Besides, he also calls attention to the "blooming" of water in the Gulf of Riga, caused evidently by Anaebaena species. In the area of Kaugern in the Gulf of Riga the author identified Fucus vesiculosus, Chorda filum, Ectocarpus sp., Furcellaria lumbricalis, Polysiphonia nigrescens, and Ceramium sp. as the most frequent species of macroalgae. Currently, basing on this work, some conclusions can be drawn as to the changes in the distribution of algal vegetation in the area.

A similar three-part work was published by two friends C. A. Heugel and C. J. G. Müller (Heugel \& Müller, 1847; Heugel, 1851-1852, Müller, 1852-1853). In the first paper attention is paid to the abundance of the bladder wrack cast ashore from the Baltic Sea. In the second work the occurrence of the species Chara aspera Willd. in the sea near Kuressaare, and Ch. crinita, Ch. hispida L., and $C h$. tomentosa L. at Kura beach was mentioned. The third work describes bladder wrack accumulations on the sandy sea floor below the Mustjala cliff.

Schmidt's "Flora des silurischen Bodens von Ehstland, Nord-Livland und Ösel" (1855) mentions five species of Chara occurring in the sea. Two parts of "Blicke in die Cryptogamenwelt der Ostseeprovinzen" by Dietrich $(1856,1859)$ belong to the same period. In these papers five species of macroalgae are mentioned and the works by Grindel (1803) and Fischer (1791) are cited. In his article "Algen des 
Rigaschen Meerbusens" (1866) Bushe names 12 species of macroalgae collected on the beach in the vicinity of Dubultu (Dubbeln), the Gulf of Riga. These species are Cladophora crystallina Kütz., C. seriacea Kütz., Enteromorpha intestinalis Link, a capillaris and b crispa, Ectocarpus litoralis Ag., Chorda filum Lam., Fucus vesiculosus L., Furcellaria fastigiata Lam., Gymnogongrus plicatus Kütz., Ceramium diaphanum (Lightf.) Roth, and Polysiphonia nigrescens Grev.

About ten years later (1877) Winkler's review "Literatur und Pflanzenverzeichnis der Flora Baltica" was published. Unfortunately, it does not mention the exact places where one or another species of algae was found. The list of references contains publications covering a wide time span, starting with Fischer (1791); however, not all the works published by that time are included. Of the 70 species of algae listed, more than 40 were evidently found growing in the sea. The next work by the same author "Über einige für die Ostseeprovinzen neue Characeen" (Winkler, 1878) is the first to cite the finds by other researchers in the Gulf of Riga (and elsewhere). The species mentioned include Ch. aspera Willd. in Kuressaare Bay; Ch. crinita Wallr. in Kurland, Ch. vulgaris, Ch. hispida, and Ch. baltica are mentioned as occurring "... in Oesel...", and it is not clear where these species were exactly found. Ch. baltica Fr. var. fasciculata Fr. was found in the sea. He mentions the abundant occurrence of Nitella nidifica Ag. in the coastal waters of Saaremaa and Hiiumaa islands, the frequent occurrence of Ch. hispida in Haapsalu and Kuressare bays, and the finds of Ch. nolteana Al. Br. $(=C h$. baltica Fr. var concinna) in the vicinity of the islands of Abruka and Vilsandi.

Gobi in his papers on the Gulf of Finland $(1874,1877)$ presents some data on the algae in Kuressaare Bay. He names the species Ectocarpus siliculosus (Dillw.) Lyngbye, Lithoderma fatiscens Aresch., Gobia baltica (Gobi) Reinke, Dictyosiphon foeniculaceus Grev., Stictyosiphon tortilis (Rupr.) Reinke, Chorda filum Lam., Fucus vesiculosus L. + var. nanus C. Ag., Furcellaria fastigiata Lam., Phyllophora brodiaei (Turn.) J. Ag., Polysiphonia nigrescens Grev. a fucoides Harv., and Hildenbrandia prototypus Nardo.

Artzichovskij's series of papers on the dwarf forms of Fucus vesiculosus was published in the early 20th century (1902-1903, 1905, 1907). The algae were studied in Kuressaare Bay, where the author considered the dwarf specimens of bladder wrack as degenerated forms. His standpoint was criticized by Elenkin (1906), who maintained that morphological changes in plants had been caused by low salinity and unfavourable environmental conditions. The problem has not been convincingly solved in the world literature as yet.

In the first years of the independent Baltic States (and even before that), Finnish, Swedish, and Danish researchers used to make short field trips to the Gulf of Riga and the area of the West Estonian islands. Svedelius (1902) identified 17 species and forms of algae at the coast of Hiiumaa; Eklund (1927-1928, 1929) made his research at the coasts of Hiiumaa and Vormsi; Häyrén (1929-1930) in the vicinity of Tallinn, Pakri Islands, Ragöarna, Vormsi, Vilsandi, and (1936-1937) at the coast of Saaremaa; Åberg (1933) on the Paldiski Peninsula and the Pakri Islands. 
Skuja's (1924) research on the algae at the south and west coasts of the Gulf of Riga was published in Acta Universitatis Latviensis. He mentions 7 taxa of Enteromorpha, 10 species of Cladophoraceae, 8 species or forms of Chara, 3 taxa of Pilayella, 3 taxa of Ectocarpus, Sphacelaria racemosa var. arctica Harv., Stictyosiphon tortilis (Rupr.) Reinke, 3 taxa of Dictyosiphon, Gobia baltica (Gobi) Reinke, Elachista fucicola (Velley) Fr., Castagnea virescens (Carm.) Thur., Chorda filum (L.) Stackh., Lithoderma fatiscens Aresch., Fucus vesiculosus f. angustifolia C. A. Ag., Anfeltia plicata (Huds.) Fries, 2 taxa of Polysiphonia, Rhodomela subfusca (Woodw.) Ag., Callithamnum byssoideum Arnott., 2 species of Ceramium, Furcellaria fastigiata + f. aegagropila Reinke, and Hildenbrandia prototypus Nardo, altogether more than 50 species.

A detailed survey of the bladder wrack and its economic importance was published by Lepik (1925). The distribution of the bladder wrack at the west and north coasts of the Gulf of Riga was mapped. A list of 18 species found in the algae cast ashore was also presented. Two years later Dannenberg (1927) in "Vorarbeiten zu einer Algenflora des Ostbaltischen Gebietes" presented a floristic list that includes the following species: Enteromorpha intestinalis, E. clathrata, Cladophora rupestris, Tolypella nidifica a condensata, Chara crinita, Ch. aspera, Ch. ceratophulla, Pilayella littoralis, Ectocarpus siliculosus, Sphacelaria racemosa + var. arctica, Chorda filum f. pumila, Fucus vesiculosus + var. angustifolia + f. baltica, Phyllophora parvula + f. angustifrons, Polysiphonia violacea var. tenuissima, P. nigrescens, Rhodomela subfusca, 3 species of Ceramium, Furcellaria fastigiata + f. aegagropila.

Lippmaa (1935) mentions the massive occurrence of Monostroma balticum in Kuressaare Bay, where the species occurs partly as a loose sea-floor organism.

A paper by Hasslow (1939) names two algal species in the Gulf of Riga: Tolypella nidifica and Chara tomentosa $\mathrm{L}$. (= Ch. ceratophylla Wallroth).

As already mentioned, in the above publications the authors mostly gave various lists of species, but usually the precise locations of findings and information about the environmental conditions are lacking.

\section{QUANTITATIVE STUDIES}

After World War II there was a 15-year period of standstill. On the one hand, it was due to the lack of researchers. On the other hand, under the Soviet occupation access to the seaside was strictly restricted. It was not until the end of the 1950s and the beginning of the 1960s that the first young specialists became engaged in the research on algae. In $1961 \mathrm{~T}$. Pullisaar-Trei published her paper on the bottom vegetation of Pärnu Bay in the Proceedings of the Estonian Academy of Sciences. This marks the beginning of the second period of phytobenthos investigations in the Gulf of Riga. The particular studies were started as early as 1959 and they lasted for three years. Since then besides Pärnu Bay the whole northern part of the Gulf of Riga was studied in detail, first by means of dredges 
and other technical devices. Since 1961 SCUBA divers have been used, which enabled to initiate quantitative studies, but also to determine algal communities and the biomass of species. These studies resulted in a number of scientific works. Two main publications, based on 15 years of phytobenthos studies, were a book on brown and red algae in the coastal waters of western Estonia (Trei, 1976) and an article on green algae and charophytes in the coastal waters of western Estonia (Trei, 1977), both in Russian. These two works give complete lists of phytobenthos species with distribution maps. Quantitative data and a classification of phytobenthos communities were presented in a dissertation defended in 1973 (Trei, 1973a) as well as in other publications (Trei, 1973b, 1975). The species composition of phytobenthos in western Estonia, including the northern part of the Gulf of Riga, is described also in some other papers (Trei \& Kukk, 1974), which in fact repeat the results presented in previous publications.

At the same time some Latvian investigators started to describe the littoral vegetation on the southern coast of the Gulf of Riga. A list of 59 species of different varieties and forms of benthic algae found in the southern part of the Gulf of Riga in 1965-1966 and 1969-1970 is given by Kumsare et al. (1974). Of these 12 forms were blue-green algae (Cyanophyta), 12 diatom algae (Bacillariophyta), 18 green algae (Chlorophyta), 8 brown algae (Phaeophyta), and 9 rhodophyll algae (Rhodophyta). A brief review of the algological investigations in the period starting from World War I carried out in the territorial waters of the Soviet Union, including also the Gulf of Riga, is given by Rudzroga (1974). A bibliography of 72 works is attached including also some works published in the 19th century.

The works dealing with marine benthic vegetation as a commercial raw material may be regarded as a new direction in the phytobenthic investigations in this area. In fact, the first real quantitative estimations of phytobenthos biomass in the region were made for the assessment of potential economic resources (Kireeva, 1960). In 1961 Kireeva published a paper on the reserves of Furcellaria fastigiata in the area of Saaremaa and Hiiumaa in the Russian language. A year later, Pullisaar-Trei's paper on the possibilities of using Estonian marine vegetation in the Estonian language appeared in the scientific-technical journal Kalatööstus (Fishing Industry) (Pullisaar, 1962). In both these works the main stress was laid on the possibility of commercial exploitation of various species of red algae, mainly Furcellaria lumbricalis for agar production. The discovery of vast amounts of loose, unattached red alga $F$. lumbricalis in the area between Saaremaa and Hiiumaa islands was published by Kireeva $(1964,1965 \mathrm{a}, \mathrm{b})$. The agar production based on local raw material started in the region in 1967.

Three papers dealing with the peculiarities of the growth of Furcellaria spp. in the Gulf of Riga and neighbouring sea areas were published in the 1970s (Blinova, 1971, 1977; Blinova \& Tolstikova, 1972).

Of great interest in terms of quantitative assessment of algal communities in the Gulf of Riga is the annual report of the Baltic Department of the All-Union Institute of Fisheries Research and Oceanology from the year 1973 (Kalnozols, 1973). In the chapter on the distribution and ecology of benthic algae in the Gulf 
of Riga a detailed description of the habitats on the western and eastern coasts, altogether at a length of $230 \mathrm{~km}$, is given with quantitative estimations of the total biomass of the algal communities (Tables 1 and 2). According to this material, 93.4\% of the total macroalgal biomass in this area is formed by Fucus vesiculosus. The share of all other species was described as very small.

The most recent data about the distribution of commercially usable red algae communities are presented in a series of publications by a group of Latvian researchers (Korolev et al., 1983, 1991a, 1993; Muravsky et al., 1988; Kuznetsova et al., 1989). These works link the tremendous decline of Furcellaria communities in the whole eastern Baltic to the increased oil pollution. Some modern techniques of underwater research such as underwater TV and aerophotography were used during these investigations. In these works also some rough biomass estimations are given. The same group of researchers has published a number of works dealing with the construction and cultivation of artificial reefs in the coastal areas of the NE Baltic Sea (Korolev et al., 1989, 1990, 1991b; Korolev, 1991).

In terms of long-term changes of the structure of phytobenthic communities related to the eutrophication of coastal waters, Pärnu Bay is the best studied area in the Gulf of Riga. Research into the species composition of the phytobenthos in Pärnu Bay was started in 1959 when Pullisaar-Trei took phytobenthos samples at

Table 1. Total biomass of the algal communities in the southern Gulf of Riga (wet weight) according to Kalnozols (1973)

\begin{tabular}{l|r|c|c|r}
\hline \multicolumn{1}{c|}{ Location } & $\begin{array}{r}\text { Area, } \\
\mathrm{km}^{2}\end{array}$ & $\begin{array}{c}\text { Mean coverage, } \\
\%\end{array}$ & $\begin{array}{c}\text { Biomass, } \\
\mathrm{kg} / \mathrm{m}^{2}\end{array}$ & $\begin{array}{r}\text { Total biomass, } \\
\mathrm{t}\end{array}$ \\
\hline Roja & 0.23 & 60 & 1.284 & 295.3 \\
Kaltene & 1.65 & 70 & 1.820 & 3003.0 \\
Upesgrīva & 2.76 & 40 & 0.720 & 1987.1 \\
Mērsrags & 4.56 & 40 & 1.672 & 7624.3 \\
Engure & 14.95 & 50 & 1.252 & 18717.4 \\
Ragaciems & 0.38 & 60 & 1.584 & 598.8 \\
Bigaunciems & 1.05 & 50 & 1.030 & 1081.5 \\
Kaugurciems & 4.18 & 60 & 1.154 & 4825.4 \\
Ainaži & 3.15 & 30 & 0.918 & 2891.7 \\
Kuiviži & 17.50 & 15 & 0.111 & 1942.5 \\
Salacgrīva & 19.20 & 50 & 1.200 & 22980.0 \\
Vitrupe & 3.20 & 30 & 0.780 & 2496.0 \\
Kutkajurags & 1.44 & 15 & 0.201 & 289.4 \\
Kurmpags & 7.20 & 50 & 1.780 & 12816.0 \\
Latchi & 2.34 & 30 & 0.738 & 1726.9 \\
Sculte & 2.10 & 50 & 1.070 & 2247.0 \\
Saulkrasti & 1.20 & 30 & 0.624 & 748.8 \\
$\quad$ Total & 87.09 & & & 86271.1
\end{tabular}




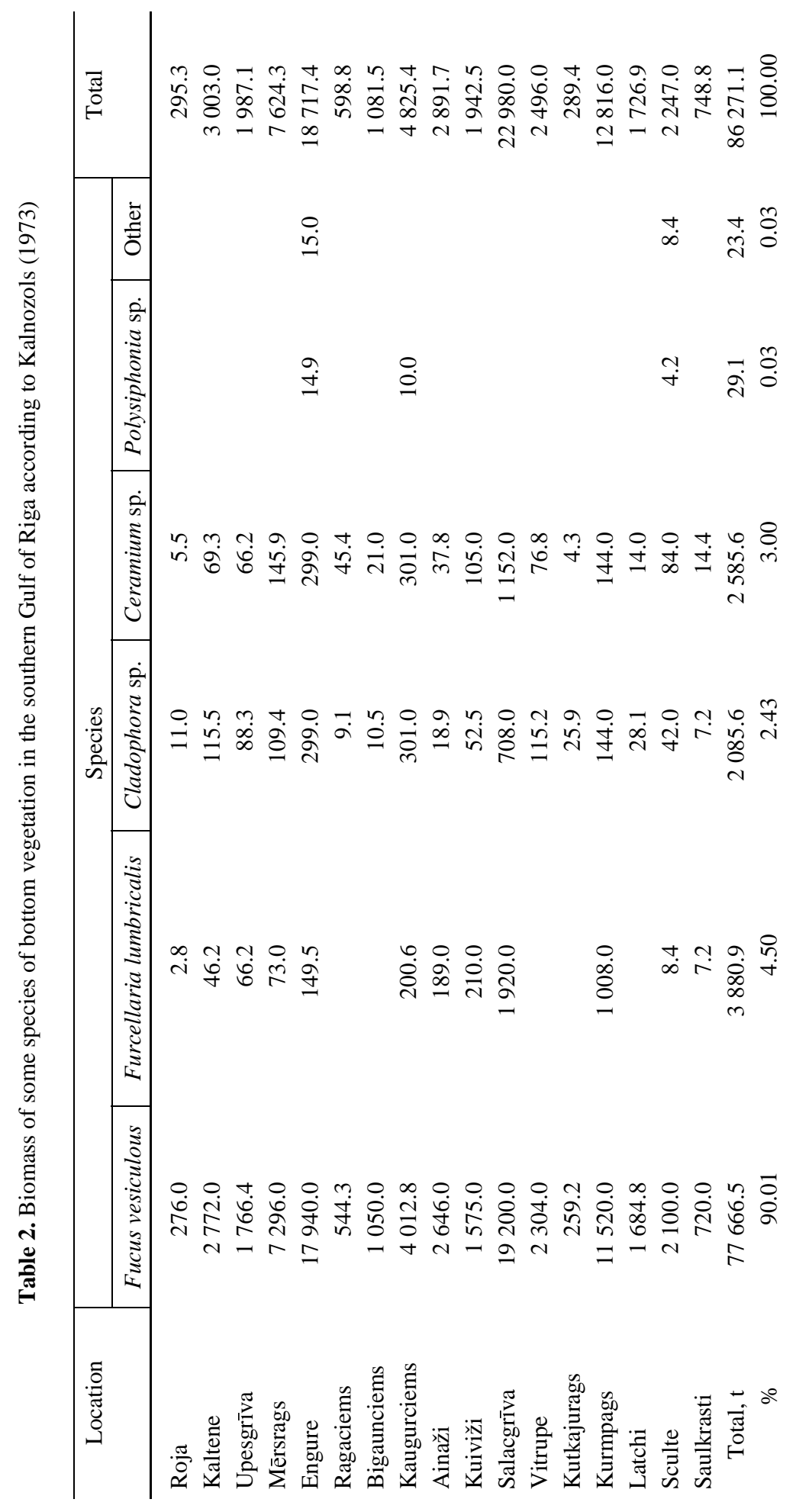


71 stations in Pärnu Bay and in the surroundings of Kihnu Island (Pullisaar, 1961; Trei, 1976). Sampling was repeated in 1979, 1980, and 1982 at 120 stations (Trei, 1984, 1986). The results obtained were generalized and presented in a book (Trei, 1991). The most recent data are available from the sampling in 1991 made by Kukk and Martin (Kukk \& Martin, 1992) at 48 stations.

A useful source of information about algal investigations in the area is a literature review concerning hydrobotanical investigations in the coastal waters of the Soviet Union published by Trei (1982). This work includes 161 references covering both benthic and pelagic investigations, including those in the Gulf of Riga. In the works published during the 1990s, the focus is mostly on the following of long-term changes in the phytobenthic zone of the Gulf of Riga. The drastic changes in the species composition of the whole Gulf of Riga during the last 60-70 years were described by Kukk $(1993,1995,1996)$ based on sampling in 1984, 1987, and 1990 and data available from the literature.

Some data about the abundance of various species of benthic algae in the ecosystem of the Gulf of Riga can be found in the work by Laganovska \& Kachalova (1990). According to them the total number of species of benthic algae in the Gulf of Riga is 39, which makes it the poorest region in the Baltic in terms of benthic algae. According to the most recent check-list of macroalgae in the Baltic Sea region, published in 1995, the number of species for the area is 49 (Nielsen et al., 1995).

The "Gulf of Riga Project" initiated by the Nordic Council of Ministers in 1993 resulted in two papers describing the quantitative distribution of phytobenthos in the Gulf of Riga (Kautsky et al., 1999; Martin, 1999). The results of these investigations together with data from other national and international projects were used in the $\mathrm{PhD}$ dissertation by Martin (2000). In this work the present distribution of phytobenthos is given together with the historical background and analyses of the environmental forcing of phytobenthos communities in the area.

Short-term changes of the phytobenthic communities on the southern coast of Saaremaa Island and in Pärnu Bay are described in the review on the results of the monitoring of phytobenthos communities as a part of the Estonian National Marine Monitoring Programme (Martin et al., 2003). The decline of the bladder wrack community in Kõiguste Bay in the middle of the 1990s is covered by the Fourth Periodic Assessment of the state of the Baltic Sea issued by HELCOM (Martin, 2002). Data on the quantitative distribution of phytobenthic communities in Kõiguste Bay have been published also in a series of ecological investigations carried out in this area (Kotta et al., 2000; Orav et al., 2000; Reitalu et al., 2002). Long-term changes in the distribution of several charophyte species in enclosed sea bays of the northeastern part of the Gulf of Riga are described by Torn \& Martin (2003). Series of ecological in situ experiments have been carried out in the northern part of the Gulf of Riga (Kõiguste Bay) to study the grazing effect on phytobenthic communities (Orav-Kotta \& Kotta, 2003, 2004; Orav-Kotta, 2004).

A comparative list of species of macrophytobenthos ever found in the waters of the Gulf of Riga, based on historical publications and recent findings, is given in Table 3. 
Table 3. Comparative list of the species identified from the phytobenthos of the Gulf of Riga by different authors

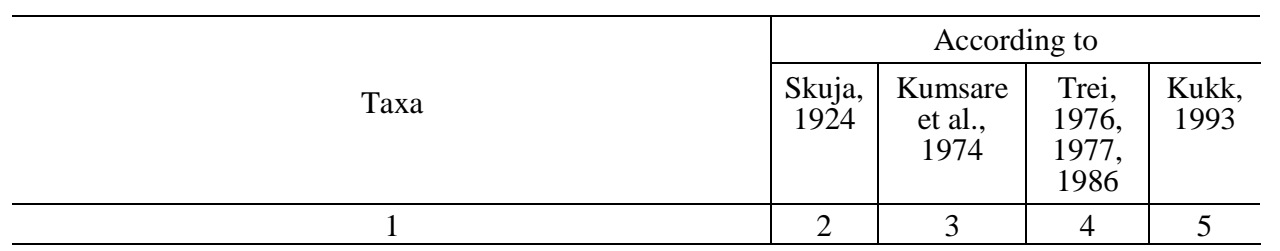

\section{Rhodophyta}

Anfeltia plicata (Huds.) Fries

Asterocytis ramosa (Thwaites in Harvey) Gobi ex Schmitz

Polyides rotundus (Huds.) Grev.

Callithamnion roseum (Roth.) Lungb.

Ceramium tenuicorne (Kütz.) Waern

C. rubrum (Huds.) C. Ag.

Furcellaria lumbricalis (Huds.) Lamour.

Hildenbrandia rubra (Sommerf.) Menegh.

Phyllophora truncata (Pallas) Zinova

Polysiphonia nigrescens (Huds.) Grev.

$P$. violacea (Roth.) Spreng.

Rhodomela confervoides (Huds.) Silva

\section{Phaeophyta}

Pilayella littoralis (L.) Kjellm.

Ectocarpus siliculosus (Dillw.) Lyngb.

Sphacelaria arctica Harvey

Sph. plumigera Holmes

Pseudolithoderma subextensum (Waern) Lund

Elachista lubrica Rupr.

Stictyosiphon tortilis (Rupr.) Reinke

Dictyosiphon foeniculaceus (Huds.) Grev.

D. chordaria Aresch.

Eudesme virescens (Carm.) J. Ag.

Chorda filum (L.) Stackh.

Fucus vesiculosus L.

\section{Chlorophyta}

Ulothrix tenerrima Kütz.

$U$. subflaccida Wille

$U$. zonata (Weber et Mohr.) Kütz.

Capsosiphon fulvescens (C. Ag.) Setch. et Gardn.

Enteromorpha ahlneriana Bliding

E. intestinalis (L.) Link

E. prolifera (O. F. Müll.) I. Ag.

E. pilifera Kütz.

Percusaria percursa (C. Ag.) Bory in Dupperrey

Chaetomorpha linum (O. F. Müll.) Kütz.

Cladophora fracta (Dillw.) Kütz.

C. glomerata (L.) Kütz.

C. rupestis (L.) Kütz. 
Table 3. Continued

\begin{tabular}{|c|c|c|c|c|}
\hline \multirow[b]{2}{*}{ Taxa } & \multicolumn{4}{|c|}{ According to } \\
\hline & $\begin{array}{c}\text { Skuja, } \\
1924\end{array}$ & $\begin{array}{c}\text { Kumsare } \\
\text { et al., } \\
1974\end{array}$ & $\begin{array}{l}\text { Trei, } \\
1976, \\
1977, \\
1986\end{array}$ & $\begin{array}{c}\text { Kukk, } \\
1993\end{array}$ \\
\hline 1 & 2 & 3 & 4 & 5 \\
\hline Rhizoclonium riparium (Roth) Harvey & + & + & + & + \\
\hline Urospora penicilliformis (Roth) Aresch. & + & - & + & + \\
\hline Oedegonium sp. & - & - & + & + \\
\hline Spirogyra sp. & + & - & + & + \\
\hline Zygnema sp. & + & - & + & + \\
\hline \multicolumn{5}{|l|}{ Charophyta } \\
\hline Chara aspera Willd. & + & - & + & + \\
\hline Ch. baltica Bruz. em Wahist. & + & - & + & - \\
\hline Ch. canescens Desv. et Lois. & + & - & + & + \\
\hline Ch. connivens Salzm. & + & - & - & - \\
\hline Ch. tomentosa $\mathrm{L}$. & + & - & - & - \\
\hline Tolypella nidifica Braun. & + & - & + & + \\
\hline \multicolumn{5}{|l|}{ Magnoliophyta } \\
\hline Myriophyllum spicatum $\mathrm{L}$. & & & + & + \\
\hline Najas marina $\mathrm{L}$. & & & + & + \\
\hline Potamogeton filiformis Pers. & & & + & + \\
\hline P. pectinatus $\mathrm{L}$. & & & + & + \\
\hline P. perfoliatus $\mathrm{L}$. & & & + & + \\
\hline Ranunculus baudotii Godr. & & & + & + \\
\hline Ruppia maritima $\mathrm{L}$ & & & + & + \\
\hline Zannichellia palustris L. & & & + & + \\
\hline Zostera marina $\mathrm{L}$. & & & + & + \\
\hline Schoenoplectus lacustris (L.) Palla & & & + & + \\
\hline Sch. tabernaemontanii (C. C. Gmel.) Palla & & & + & + \\
\hline Bolboschoenus maritimus (L.) Palla & & & + & + \\
\hline Phragmites australis (Cav.) Trin. ex Steud. & & & + & + \\
\hline
\end{tabular}

\section{ACKNOWLEDGEMENTS}

The present study was initiated and funded as part of the "Littoral" subproject in the framework of the "Gulf of Riga Project" carried out during the years 19921997. The authors appreciate the valuable comments made by the project group, including the leader of the subproject Dr. Daniel Conley, and also by Pentti Kangas, Anita Mäkinen, and Hans Kautsky. The work on the updating of the manuscript after a long delay with the publication was carried out in the framework of Estonian governmental programme No. 0182578s03 and publication was made possible with support from grants Nos. 5927 and 5103 of the Estonian Science Foundation. The authors wish to thank an anonymous referee for valuable comments and suggestions. 


\section{LIST OF THE OVERVIEWED LITERATURE}

Åberg, G. 1933. Floristische Beobachtungen bei Baltischport und auf den Inseln Ragöarna (Pakri saared) in NW-Estland. Mem. Soc. Fauna Flora Fenn., 10, 222-239.

Artzichowsky, V. M. 1902-1903. Über die Formen von Fucus vesiculosus L. (Vorläuf. Mitteil.). Trav. Soc. Natural. St.-Petersbourg, 33(1), Comptes-rendeus des seances, 8, 335-337.

Artzichowsky, V. M. 1905. Des formes naines de Fucus vesiculosus L. se rattachant, à la question de la degeneration. Trav. Jardin St.-Petersbourg, 24, 357-536.

Artzichowsky, V. M. 1907. Phylonecrouse ou bien l'adaptation? Reponse à M-r Elenkin. Trav. Soc. Natural. St. Petersbourg, 36(3), 13-16.

Blinova, E. I. 1971. Amount and dynamics of washed ashore Furcellaria on the coasts of the Baltic Sea. Rybn. Khozj., 7, 10-12 (in Russian).

Blinova, E. I. 1977. Peculiarities of the growth of Furcellaria fastigiata (Huds.) Lamour in the Gulf of Riga. Rastit. Resur., 13, 113-119 (in Russian).

Blinova, E. I., \& Tolstikova, N. E. 1972. Amount of economically usable agar containing algae Furcellaria fastigiata (Huds.) Lamour near Lithuanian coasts. Rastit. Resur., 8, 380-388 (in Russian).

Bushe, T. B. 1866. Algen des Rigaschen Meerbusens. Korrespondenzblatt Naturforsch. Vereins Riga, 15(13), 27-28.

Dannenberg, W. 1927. Vorarbeiten zu einer Algenflora des Ostbaltischen Gebietes. Korrespondenzblatt Naturforsch. Vereins Riga, 59, 129-144.

Dietrich, H. A. 1856. Blicke in die Cryptogamenwelt der Ostseeprovinzen. Arch. Naturk. Liv-, EhstKurlands, II Ser., 1(4), 261-416.

Dietrich, H. A. 1859. Blicke in die Cryptogamenwelt der Ostseeprovinzen. Zweite Abteilung. Arch. Naturk. Liv-, Ehst- Kurlands, II Ser., 1(5), 487-538.

Eichwald, E. 1847. Erster Nachtrag zum Infusorienkunde Russlands. Bull. Soc. Imp. Natural. Moscou, 20(1), 285-366.

Eichwald, E. 1849. Zweiter Nachtrag zum Infusorienkunde Russlands. Bull. Soc. Imp. Natural. Moscou, 22(2), 400-548.

Eichwald, E. 1852. Dritter Nachtrag zum Infusorienkunde Russlands. Bull. Soc. Imp. Natural. Moscou, 25(1), 388-536.

Eklund, O. 1927-1928. Notizen über die Flora des nördlichen und westlichen Dagö (Hiiumaa) in Estland. Mem. Soc. Fauna Flora Fenn., 4, 192-230.

Eklund, O. 1929. Beiträge zur Flora der Insel Vormsö. Acta Soc. Fauna Flora Fenn. Vanamo, 55(9), 1-136.

Elenkin, A. A. 1906. Note sur l'article de M. Artzichowsky: "Formes naineuses de Fucus vesiculosus L. et la question de la degeneration". J. Bot. Prem. Ann. 1. Trav. Soc. Natural. St. Petersbourg, 35(3), 21-33.

Fischer, J. (L). 1778. Versuch einer Naturgeschichte von Livland. Leipzig.

Fischer, J. B. 1784. Zusätze zu seinem Versuch einer Naturgeschichte von Livland. Köningsberg.

Fischer, J. B. 1791. Versuch einer Naturgeschichte von Livland. 2. Auflage. Leipzig.

Friebe, W. Ch. 1805. Oeconomisch-technische Flora für Liv-, Ehst- und Kurlands. Riga.

Gobi, Chr. 1874. Die Brauntange (Phaeosporeae und Fucaceae) des Finnischen Meerbusens. Mem. acad. Imp. Sci. Petersbourg, VII Ser., 21(9), 1-21.

Gobi, Chr. 1877. Die Rothtange des Finnischen Meerbusens. Mem. Acad. Sci. St.-Petersbourg, VII Ser., 24(7), 1-16.

Grindel, D. H. 1803. Botanisches Taschenbuch für Liv-, Kur- und Ehstlands. Riga.

Häyrén, E. 1929-1930. Einige Algenfunde an den Meeresküsten Estlands. Mem. Soc. Fauna Flora Fenn., 6, 174-179. 
Häyrén, E. 1936-1937. Algenfunde 1935 von den Insel Ösel und von einigen Nachbarinseln. Mem. Soc. Fauna Flora Fenn., 12, 180-185.

Hasslow, O. J. 1939. Einige Characeenbestimmungen. Bot. Not., 295-301.

Heugel, C. A. 1851-1852. Bemerkungen und Beiträge zur Flora der Ostseeprovinzen. Korrespondenzblatt Naturforsch. Vereins Riga, 5, 113-152.

Heugel, C. A. \& Müller, C. 1847. Zur Flora Ostseeprovinzen. VII. Korrespondenzblatt Naturforsch. Vereins Riga, 2, 48-50, 69-71.

Kalnozols, P. A. 1973. The distribution and ecology of benthic algae in the Gulf of Riga. In The Annual Report of the Riga Department of All-Union Institute of Fisheries Research and Oceanology, pp. 100-109 (in Russian).

Kautsky, H., Martin, G., Mäkinen, A., Borgiel, M., Vahteri, P. \& Rissanen, J. 1999. Structure of phytobenthic and associated animal communities in the Gulf of Riga. Hydrobiologia, 393, 191-200.

Kireeva, M. S. 1960. Distribution and biomass of algae in the Baltic Sea. Tr. VNIRO, 42, 195-205 (in Russian).

Kireeva, M. S. 1961. Amount of Furcellaria fastigiata (Huds.) Lamour in the Baltic Sea (area of Saaremaa and Hiiumaa Islands). Tr. NIIRH SNH Latv. SSR, 3, 411-417 (in Russian).

Kireeva, M. S. 1964. Aggregations of unattached red algae in the sea areas of Soviet Union. In Resources of Marine Algae and Their Use, pp. 1-25. Moscow (in Russian).

Kireeva, M. S. 1965a. Commercial resources of algae in the coastal seas of Soviet Union. Okeanologiya, 5(1), 14-21 (in Russian).

Kireeva, M. S. 1965b. Valuable algae (production of agar in the Baltic Sea). Priroda, 3, 100-102 (in Russian).

Korolev, A. P. 1991. Peculiarities of the application of artificial reefs and substrates in coastal region of the Baltic Sea. In Proc. Intern. Conf. "Methods of Investigation and the Use of Hydrosystems", p. 173. University of Latvia, Riga.

Korolev, A. P., Muravsky, V. I. \& Prytkov, E. I. 1983. Washed ashore Furcellaria and its characteristics in the Baltic Sea. In Fisheries Research in the Baltic Sea Basin, 18, pp. 95-102. Riga (in Russian).

Korolev, A. P., Kuznetsova, T. A., Kadnikov, V. B. \& Nazarenko, A. N. 1989. The use of artificial reefs for the melioration of the Baltic Sea. In Proc. Intern. Conf. "Todays Problems of Marine Culture", pp. 58-60. VNIRO, Moscow.

Korolev, A. P., Kadnikov, V. B, Kuznetsova, T. A., Muravsky, V. I., Nazarenko, A. N., Zake, A. \& Drozdetsky, V. G. 1990. Investigation of the application of the artifical constructions in the coastal region of the Baltic Sea. In Artificial Reefs for Fishery Farms, pp. 166-176. VNIRO, Moscow (in Russian).

Korolev, A. P., Kuznetsova, T. A. \& Drozdetsky, V. G. 1991a. Monitoring of stock of agar-rich sea weed in the coastal region of the Baltic Sea. In Proc. Intern. Conf. "Methods of Investigation and the Use of Hydrosystems", pp. 64-65. University of Latvia, Riga.

Korolev, A. P., Kuznetsova, T. A., Kadnikov, V. B. \& Drozdetsky, V. G. 1991b. Artificial reefs in the coastal zone of the Baltic Sea. Fisch. Forsch., 2, 57-60.

Korolev, A., Kuznetsova, T. \& Drozdetsky, V. 1993. Investigations of the Furcellaria lumbricalis distribution and abundance at the eastern coast of the Baltic Sea. ICES, Baltic Fisheries Committee, L:39.

Kotta, J., Orav, H., Martin, G. \& Mäkinen, A. 2000. Major changes in macroalgae community composition affect the food and habitat preference in Idotea baltica. Int. Rev. Hydrobiol., 85, 693-701.

Kukk, H. 1993. Floristic composition of the phytobenthos and its long-term changes in the Gulf of Riga, the Baltic Sea. Proc. Estonian Acad. Sci. Ecol., 3, 85-91.

Kukk, H. 1995. Phytobenthos. In Ecosystem of the Gulf of Riga between 1920 and 1990, pp. 131-138. Estonian Academy Publishers, Tallinn. 
Kukk, H. 1996. Macrophytobenthos. Gulf of Riga. Third Periodic Assessment of the State of the Marine Environment of the Baltic Sea, 1989-1993. Baltic Sea Environ. Proc., 64B, 73.

Kukk, H. \& Martin, G. 1992. Long-term dynamics of the phytobenthos in Pärnu Bay, the Baltic Sea. Proc. Estonian Acad. Sci. Ecol., 2, 110-118.

Kumsare, A., Jurane, A. \& Liepa, R. 1974. Algal flora and protozoa in the littoral zone of the southern part of the Gulf of Riga. In Biology of the Baltic Sea, 1, 130-143. Riga.

Kuznetsova, T. A., Drozdetsky, V. G. \& Korolev, A. P. 1989. Study of the distribution and amounts of Furcellaria in coastal areas of the Baltic Sea. In Proceedings of the IV All-Union Science and Technical Conference "Contribution of Young Scientists in Solving the Problems of Modern Oceanology and Hydrobiology”, 6. Sevastopol (in Russian).

Laganovska, R. J. \& Kachalova, O. L. 1990. Hydrobiological Investigations in the Baltic Sea Area. Riga (in Russian).

Lepik, E. 1925. Põisadru (Fucus vesiculosus L.) ja selle majanduslik tähtsus. Agronoomia, 5(4), $135-144$.

Lippmaa, T. 1935. Meriheinast ja teistest Eesti rannikuvete taimedest. Eesti Loodus, 4(5), 177-183.

Luce, J. W. L. von. 1823. Topographische Nachrichten von der Insel Oesel in medizinischer und ökonomischer Hinsicht. Riga.

Martin, G. 1999. Distribution of phytobenthos in the Gulf of Riga (years 1984-1991). Hydrobiologia, 393, 181-190.

Martin, G. 2000. Phytobenthic communities of the Gulf of Riga and the inner sea of the WestEstonian Archipelago. Diss. Biol. Univ. Tartu., 64.

Martin, G. 2002. Benthic vegetation. Gulf of Riga. In Environment of the Baltic Sea Area 19941998. Baltic Sea Environ. Proc. 82B, 96-97.

Martin, G., Torn, K., Kotta, J. \& Orav-Kotta, H. 2003. Estonian marine phytobenthos monitoring programme: preliminary results and future perspectives. Proc. Estonian Acad. Sci. Biol. Ecol., 52, 112-124.

Muravsky, V. I., Korolev, A. P. \& Kuznetsova, T. A. 1988. The state of the Furcellaria in the Baltic Sea and possibilities of its recovery. Rybn. Khoz., 3, 13-14 (in Russian).

Müller, C. 1852-1853. Versuch eines Vegetationsgemäldes von Oesel. Korrespondenzblatt Naturforsch. Vereins Riga, 6, 1-26.

Nielsen, R., Kristiansen, A., Mathiesen, L. \& Mathiesen, H. 1995. Distributional index of the benthic macroalgae of the Baltic Sea area. Acta Bot. Fenn., 155, 1-51.

Orav-Kotta, H. 2004. Habitat choice and feeding activity of benthic suspension feeders and mesograzers in the northern Baltic Sea. Diss. Biol. Univ. Tartu., 89.

Orav-Kotta, H. \& Kotta, J. 2003. Seasonal variations in the grazing of Gammarus oceanicus, Idotea baltica, and Palaemon adspersus on benthic macroalgae. Proc. Estonian Acad. Sci. Biol. Ecol., 52, 141-148.

Orav-Kotta, H. \& Kotta, J. 2004. Food and habitat choice of the isopod Idotea baltica in the northeastern Baltic Sea. Hydrobiologia, 514, 79-85.

Orav, H., Kotta, J. \& Martin, G. 2000. Factors affecting the distribution of benthic invertebrates in the phytal zone of the north-eastern Baltic Sea. Proc. Estonian Acad. Sci. Biol. Ecol., 49, 253-269.

Pullisaar, T. 1961. Märkmeid Pärnu lahe põhjataimestiku kohta. ENSV TA Toim. Biol., 4, 340-346.

Pullisaar, T. 1962. Eesti meretaimede kasutamise võimalustest. Kalatööstus. Tead.-tehn. inform. bülletään. 1, 57-60.

Reitalu, T., Paal, J. \& Martin, G. 2002. Quantitative distribution of phytobenthic communities along Estonian exposed seashores. Proc. Estonian Acad. Sci. Biol. Ecol., 51, 257-276.

Rudzroga, A. 1974. Soviet investigations of algae in the Baltic Sea. In Biology of the Baltic Sea, 1, pp. 119-129. Riga.

Schmidt, F. 1855. Flora des silurischen Bodens von Ehstland, Nord-Livland und Ösel. Arch. Naturk. Liv-, Ehst- Kurland, II Ser., 2, 539-580. 
Skuja, H. 1924. Mersraga - Ragaciema piekrastes algas. Acta Univ. Latviensis, 10, 337-392.

Svedelius, N. 1902. Hafsalger fran Dagö. Bot. Not., 225-227.

Torn, K. \& Martin, G. 2003. Changes in the distribution of charophyte species in enclosed seabays of western Estonia. Proc. Estonian Acad. Sci. Biol. Ecol., 52, 134-140.

Trei, T. 1973a. Phytobenthos of the coastal waters of Western Estonia. Abstract of Cand. Sci. Thesis. Tartu (in Russian).

Trei, T. 1973b. Lääne-Eesti rannavete taimekoosluste klassifikatsioon. In X Eesti Looduseuurijate päev. Lühiettekanded, pp. 96-101. Tallinn.

Trei, T. 1975. Flora and vegetation in the coastal waters of Western Estonia. Merentutkimuslait. Julk., 239, 384-351.

Trei, T. 1976. Brown and Red Algae in Coastal Waters of Western Estonia. Zvaigzne, Riga (in Russian).

Trei, T. 1977. Green algae and charophytes in the coastal waters of Western Estonia. Publ. VNIRO, 124, 27-30 (in Russian).

Trei, T. 1982. A Review of Hydrobotanical Investigations in the Waters of the Soviet Baltic. Tallinn (in Russian).

Trei, T. 1984. Anthropogenic influence on the bottom vegetation in some shallow bays of western Estonia. In Hydrobiological Researches XIII, pp. 74-81. Valgus, Tallinn (in Russian).

Trei, T. 1986. The floristic composition of the phytobenthos in Pärnu Bay and in the surroundings of Kihnu Island. Proc. Acad. Sci. Estonian SSR, Biol., 35, 56-60 (in Russian).

Trei, T. 1991. Taimed Läänemere põhjal. Valgus, Tallinn.

Trei, T. \& Kukk, H. 1974. Species composition of brown and red algae of coastal areas of Estonian SSR. In All-Union Workshop on Marine Algology - Macrophytobenthos, pp. 134-137 (in Russian).

Winkler, C. 1877. Literatur und Pflanzenverzeichnis der Flora Baltica. Arch. Naturk. Liv-, EhstKurlands, Ser II, 7(4), 385-490.

Winkler, C. 1878. Über einige für die Ostseeprovinzen neue Characeen. Sitzungsber. Naturforsch. Gesellsch. Dorpat, 4, 259-266.

\title{
Liivi lahe põhjataimestiku uuringute ajalooline ülevaade
}

\author{
Georg Martin, Erich Kukk, Henn Kukk ja Jonne Kotta
}

Põhjataimestiku uuringute ajalugu Liivi lahe piirkonnas ulatub juba 18. sajandisse. Kahe ja poole sajandi jooksul on teaduslikus kirjanduses avaldatud suur hulk teoseid nii kohalikes kui Euroopas enam levinud keeltes. Käesoleva artikli eesmärgiks on anda ülevaade põhjataimestiku uuringutest Liivi lahes ja teha ingliskeelsele lugejale kättesaadavaks uuringute põhilised tulemused. Artiklis on refereeritud 85 teaduslikku publikatsiooni, mille põhjal on koostatud ka Liivi lahe põhjataimestiku liikide võrdlev nimekiri. 